\title{
Chromosome aberrations frequency in peripheral blood lymphocytes in young tobacco smoking and non-smoking people
}

\author{
Anja Haverić1* , Sanin Haverić1, Slavka Ibrulj² \\ 'Laboratory for Cytogenetics and Genotoxicology, Institute for Genetic Engineering and Biotechnology, University of \\ Sarajevo, Sarajevo, Bosnia and Herzegovina, ${ }^{2}$ Center for Genetics, Faculty of Medicine, University of Sarajevo, Sarajevo, \\ Bosnia and Herzegovina
}

\begin{abstract}
Introduction: Cigarette smoking is associated with severe health problems, especially cancers. In addition, cigarette smoking causes different genotoxic effects. Chromosome aberrations are one of well-known intermediate end points in carcinogenesis. The aim of this study was to compare frequencies of chromosome aberrations in peripheral blood lymphocytes between young smokers and non-smokes groups.

Methods: The study was conducted with 30 smokers (average age 26.93 years) and 30 non-smokers (average age 26.96 years), and included the analysis of 100 metaphases per each blood sample. Differences in the arithmetic means of determined frequencies of chromosome aberrations were tested by two-tailed $t$-test for independent samples with the significance level of $p<0.05$.
\end{abstract}

Results: The results showed a significant increase in the frequencies of chromatid-type aberrations and total structural chromosome aberrations in smoker group. Frequencies of numerical aberrations did not differ significantly between two groups.

Conclusions: This study confirmed genotoxicity of cigarette smoking and provided new evidence about its clastogenic activity.

Keywords: Tobacco genotoxicity; cytogenetic markers; lymphocytes culture

\section{INTRODUCTION}

Cigarette smoking is one of the main global health problems due to the association of cigarette smoking

\footnotetext{
*Corresponding author: Anja Haverić, Institute for Genetic Engineering and Biotechnology, University of Sarajevo, Zmaja od Bosne 8, 71000 Sarajevo, Bosnia and Herzegovina,

Tel.: +38733220926, Fax: +38733442891.

E-mail: anja.haveric@ingeb.unsa.ba
}

Submitted: 17 July 2016/Accepted: 25 September 2016

DOI: http://dx.doi.org/10.17532/jhsci.2016.368

UNIVERSITY OF SARAJEVO FACULTY OF HEALTH STUDIES with several types of cancers, including lung and larynx cancers (1). In addition, cigarette smoking has been reported to cause segregation errors in meiosis (2). Different studies found that tobacco smoke condensate induces various genetic aberrations, including gene mutations, chromosome aberrations, micronuclei $(\mathrm{MN})$, sister chromatid exchanges, DNA strand breaks, and oxidative DNA adducts, in different tissues (3). Unrepaired or misrepaired DNA double-strand breaks, that are induced or 
occur spontaneously, are considered to be the most important lesion responsible for the production of aberrations $(4,5)$. Tobacco smoke is a mixture of more than 5000 toxic and carcinogenic chemicals (6-8). DNA methylating agents, that are present also in tobacco smoke (3), generate O6-methyleguanine lesion that can be converted into sister chromatid exchange or aberrations $(9,10)$. Chromosome mutations are recognized as intermediate end points in carcinogenesis, thus, increased frequencies of chromosome mutations and micronuclei predict higher risk for cancer development $(11,12)$. Formation of free radicals is one of the major pathways by which tobacco smoke induces genetic damage leading to carcinogenesis (13). Among a large number of tests for detecting genetic damage, chromosome aberration analysis is considered as a highly suitable method for assessing the effect of tobacco smoke on chromosomes (14).

Numerous studies have indicated tobacco smoke genotoxicity. A significant increase in frequency of chromosome aberrations was found in smokers compared to non-smokers $(15,16)$. However, the majority of recent studies on cigarette smoking genotoxicity are based on the micronucleus assays in lymphocytes or exfoliated epithelial cells. The human buccal micronucleus cytome assay (BMCyt) is one of the most widely used techniques for the measurement of genetic damage in human population studies. It has been reported that micronuclei frequency is increased in heavy smoking group and that the frequency decreases with daily fruit consumption (17). Yadav and Saini found a significantly higher frequency of micronuclei, binuclear cells, and karyolysis in exfoliated buccal cells in smoker compared to non-smoker group (18). In addition, a 2.5-fold higher frequency of micronuclei in buccal mucosa is reported for bladder cancer patients exposed to tobacco (19). Naderi et al. found a significantly higher frequency of micronuclei in buccal mucosa cells of smokers, especially in the group that had been smoking for 10 years or longer (20). Genotoxicity of tobacco smoke has also been confirmed experimentally in mice exposed to mainstream cigarette smoke. The increase in MN frequency in normochromatic erythrocytes (NCE) was significantly higher in mice exposed to mainstream cigarette smoke compared to filtered air-exposed mice. Mainstream cigarette smoke also caused an elevation of bulky DNA adducts, oxidative DNA damage, and an extensive downregulation of microRNAs in lung (21). In our previous study conducted in Bosnia and Herzegovina, cigarette consumption increased the micronuclei frequency in peripheral blood lymphocytes in group of young smokers (22).

The aim of this study was to compare the frequencies of chromosome aberrations in peripheral blood lymphocytes, between young smoker and nonsmoker groups, for which micronuclei frequencies are previously reported.

\section{METHODS}

\section{Study group}

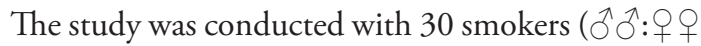
16:14), aged 21-38 years (average age 26.933), and

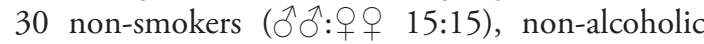
young adults, aged 21-39 (average age 26.967), from the urban area of Sarajevo (Bosnia and Herzegovina).

All participants completed informed consent form and questionnaires. The participants were considered eligible for the study under the following criteria: complete information on gender, age, and smoking status was provided, no exposure to ionizing radiation was reported except for natural background levels, and the participants smoked at least two cigarettes per day for $\geq 1$ year before the sampling. The exclusion criteria were: chronic illnesses, diabetes, and consumption of antibiotic medication or exposure to ionizing radiation 3 months before the beginning of the study. Diet factors as well as alcohol, tea, and coffee consumption were not considered. The study was approved by the Scientific Council of the Institute for Genetic Engineering and Biotechnology and conforms to the ethical standard of the Institute.

Blood samples and buccal swabs were simultaneously collected and processed for micronuclei frequency analysis that was previously reported (22), as well as for the chromosome aberration analysis conducted in this study.

In the group of smokers, the smoking period lasted from 2 to 20 years (average 8.367) while number 
of cigarettes smoked per day ranged from 7 to 30 (average 18.833), as it is presented in Table 1. Nonsmokers group consisted of never smokers, while former smokers were categorized as non-smokers only if they had been abstaining from smoking more than 5 years before sample collection (23).

\section{Lymphocyte cultivation and chromosome aberration assay}

Blood samples were collected by venipuncture into vacutainer tubes containing sodium heparin (BD Vacutainer Systems, Plymonth, UK). Whole blood, $400 \mu \mathrm{l}$ per each sample, was cultured in PBMAX $^{\mathrm{TM}}$ Karyotyping Medium (GIBCO-Invitrogen, Carlsbad, CA). Colcemid (GIBCO-Invitrogen, Carlsbad, CA), in the final concentration of $0.18 \mu \mathrm{g} /$ $\mathrm{mL}$, was added 90 minutes prior the end of cultivation. Lymphocytes were harvested 72 hours after the set-up of cultures. After hypotonic treatment with $0.075 \mathrm{M}$ potassium chloride $\left(25\right.$ minutes on $\left.37^{\circ} \mathrm{C}\right)$, the cells were fixed three times in cold acetic acid fixative, and cell suspension was dropped on coded slides. Dried slides were stained in 5\% Giemsa for 7 minutes. Microscopic analysis over 100 metaphases per sample at $1000 \times$ magnification, was performed according to the International System for Human Cytogenetic Nomenclature (24).

\section{Statistical analysis}

The mean and standard deviation were calculated using Excel (Microsoft Office 2007). Differences in arithmetic means of observed frequencies of chromosome aberrations were tested by two-tailed $t$-test for independent samples using MedCalc for Windows, version 16.2.0. (MedCalc Software, Ostend, Belgium). Effects of age and gender on the frequency of observed cytogenetical parameters were evaluated in smokers and non-smokers independently, as well as collectively, by multivariate analysis model (m independent; $\mathrm{n}$ dependent variables) in PAST software (version 3.13) (25). The same multivariate analysis model was used to test the effects of intensity and duration of smoking on the frequency of chromosome aberrations. Additionally, smoking index was calculated (Smoking index $=$ Number of cigarettes $\mathrm{x}$ Total duration of smoking during years [14]) and used to estimate its linear association and rang correlation with chromosome aberration frequencies, using MedCalc 16.2.0. The correlation between chromosome aberrations and previously observed micronuclei frequencies was also tested by Pearson's correlation coefficient using MedCalc 16.2.0. The significance level was set at $p<0.05$.

\section{RESULTS}

Chromosome aberration analysis revealed a significant increase in the frequency of chromatid-type aberrations $(p=0.02)$ and a highly significant increase in the frequency of total structural aberrations $(p=0.008)$ in smoker group. The frequencies of bichromatid (chromosome-type) aberrations in smoker group were higher in comparison to non-smoker group, although not significantly. Furthermore, numerical aberration frequencies did not significantly differ between smokers and non-smokers. Summarized results of chromosome aberration analysis in two observed groups are presented in Table 2.

The most frequent aberrations per 100 metaphases, in both analyzed groups, were chromatid breaks (1.133\% in smokers and $0.633 \%$ in non-smokers), followed by bichromatid breaks $(0.633 \%$ in smokers and $0.433 \%$ in non-smokers). Dicentric chromosome (chromosome exchange type of aberration [chre]), as the most complex aberration that was observed in this study, was evidenced in one sample from smoker group.

In order to evaluate the effect of age and gender on the frequency of chromosome aberrations, a multivariate analysis was performed. A significant effect of age and gender on the frequency of aneuploidies in smoker group was determined ( $p=0.034$ for gender; $p=0.02$ for age).

TABLE 1. Distribution of smokers by the intensity and years of smoking

\begin{tabular}{ccccccccc}
\hline & \multicolumn{4}{c}{ Smoking intensity (cigarettes per day) } & \multicolumn{3}{c}{ Years of smoking } \\
\hline & -10 & $11-15$ & $16-20$ & $21-25$ & $26-30$ & -5 & $6-10$ & $11-20$ \\
Ratio (\%) & 23.333 & 20 & 33.333 & 0 & 23.333 & 23.333 & 53.333 & 23.333 \\
\hline
\end{tabular}


TABLE 2. Frequencies of observed chromosome aberrations

\begin{tabular}{|c|c|c|}
\hline & Non-smokers & Smokers \\
\hline Gender ratio (ふふふર: & $16: 14$ & $15: 15$ \\
\hline Age (average years) & 26.967 & 26.933 \\
\hline \multicolumn{3}{|l|}{$\begin{array}{l}\text { Structural aberrations } \\
\text { cht }\end{array}$} \\
\hline chtb & $0.633 \pm 0.850$ & $1.133 \pm 0.973$ \\
\hline $\min$ & $0.067 \pm 0.254$ & $0.133 \pm 0.346$ \\
\hline Sum & $0.700 \pm 0.837$ & $1.267 \pm 0.980^{*}$ \\
\hline \multicolumn{3}{|l|}{ chr } \\
\hline chrb & $0.433 \pm 0.568$ & $0.633 \pm 0.850$ \\
\hline ace & $0.200 \pm 0.610$ & $0.300 \pm 0.651$ \\
\hline dmin & $0.133 \pm 0.346$ & $0.133 \pm 0.346$ \\
\hline chre & $0.000 \pm 0.000$ & $0.033 \pm 0.183$ \\
\hline Sum & $0.767 \pm 0.898$ & $1.100 \pm 1.062$ \\
\hline Total & $1.467 \pm 1.042$ & $2.367 \pm 1.450^{* \star}$ \\
\hline \multicolumn{3}{|l|}{ Numerical aberrations } \\
\hline \multicolumn{3}{|l|}{ Aneuploidy } \\
\hline $2 n+1$ & $0.433 \pm 0.898$ & $0.533 \pm 0.860$ \\
\hline $2 n-1$ & $0.200 \pm 0.407$ & $0.200 \pm 0.484$ \\
\hline Polyploidy & $0.033 \pm 0.183$ & $0.100 \pm 0.305$ \\
\hline
\end{tabular}

${ }^{*}$ Significantly increased compared to non-smokers $(p<0.05)$,

${ }^{* *}$ Highly significant $(p<0.01)$. Values are expressed as mean \pm standard deviation (SD); cht - chromatid-type aberrations; chtb - chromatid break; min - minute fragment; chr - chromosome type (bichromatid) aberrations; chrb - chromosome break; ace - acentric fragment; dmin - double minute; chre - chromosome exchange; $(2 n-)$ - hypodiploidies; $(2 n+)$ - hyperdiploidies

In addition to linear regression and rang correlation analyses, multivariate analysis revealed that the intensity and duration of smoking, as well as smoking index, did not significantly affect the frequency of observed chromosome aberrations, in the smoker group.

Correlation analysis of frequencies of chromosome aberrations and previously reported micronuclei frequencies, for the same individuals, showed the highest positive correlations between total structural aberration frequencies (chromatid- and chromosome-type) and micronuclei frequencies in both smoker $(r=0.352 ; p=0.056)$ and non-smoker groups $(r=0.342 ; p=0.06)$. However, significant correlations between chromosome-type aberration frequencies and previously reported micronuclei frequencies were not evidenced in the same smoker and non-smoker groups.

\section{DISCUSSION}

Since cigarette smoking is a major cause of chronic disease worldwide, the effects of cigarette smoking on genetic material are constantly being investigated. Several recent studies identified smoking-related DNA methylation sites $(26,27)$ that can cause chromosome brakes and change gene expression levels. They represent an important molecular mechanism underlying development of smoking-related disease. In genotoxicity monitoring and screening, various cytogenetic end points are used as biomarkers. Their predictive aspect for cancer risk assessment at a group level, especially of micronuclei (12) and chromosomal aberrations (28), is highly important. Our results indicate that higher frequency of chromatid and total structural aberrations are most likely related to cigarette smoking and are in agreement with previously reported results for micronuclei frequencies (22). Other analyses of micronuclei frequencies in Bosnian population also revealed the negative impact of cigarette smoking on genetic material $(29,30)$.

Numerous studies confirmed that age could have confounding effect on chromosome aberration frequencies (31). In this study, a significant effect of age and gender on the frequency of aneuploidies was demonstrated. Although the chromosome aberration assay is not a completely reliable method for detection of aneuploidies (32), numerical aberrations were observed. However, cigarette smoking may increase the risk of certain chromosome aneuploidies in germ cells, with individual differences in susceptibility to aneuploidy. Shi et al. confirmed that the frequency of disomy 13 in sperm cells was significantly higher in light and heavy smokers than in non-smokers (33). In addition, loss of chromosome $\mathrm{Y}$ in blood cells is associated with both cigarette smoking and increased risk of nonhematological tumors (34).

Other studies have found intensity (number of cigarettes smoked per day) and duration (number of smoking years) to be the most important factors influencing the damage of genetic material in smokers. In a study of Uma et al. (14), increased level of chromosome aberrations was evidenced only in the smoker group with smoking index above 300 . In our study, only two individuals in smoker group had smoking index above 300 . This may explain the lack 
of significant correlation between smoking index and chromosome aberration frequency.

Although a positive correlation between the frequencies of micronuclei and chromosome aberrations was previously reported in another study of $\mathrm{B} \& \mathrm{H}$ population (35), the frequency of micronuclei is more commonly correlated with a specific type of aberrations, such as acentric fragments and dicentric chromosomes (36). In accordance with these findings, we observed the highest positive correlation between total structural aberrations and micronuclei frequencies, both in smoker and nonsmoker groups. Significant correlations between chromosome-type aberrations and previously reported micronuclei frequency, in the smoker and non-smoker groups were not evidenced, confirming the role of chromatid fragments in micronuclei formation (37).

The findings presented in this study, especially those that revealed a statistically significant increase in frequencies of structural chromosomal aberrations in smoker group, are in accordance with published data about genotoxicity of cigarette smoking $(3,14,16-20)$. A study of over 970 adolescents in Bosnia and Herzegovina, 17 to 18 years old, showed that $30 \%$ of young men and $32 \%$ of young women smoke (38), and some of them started smoking as early as 13 years of age (39). The incidence of smoking is also reported to be high in Croatia (27.4\%) (40) and Kosovo (31\% for adolescent males and $40 \%$ for adolescent women) (41). Although a significant decrease in tobacco consumption has been observed globally from 2002 to 2010, this trend is still lagging behind in Eastern Europe (42). At the same time, living in the urban environment should be considered as a higher risk factor for substances use, especially in females (43).

This study is a continuation of genotoxicological monitoring of Sarajevo population using cytogenetics methods. In 2006, we started with a study on war and postwar genotoxin effects on micronuclei frequency in a group from Sarajevo (44), as a contribution to the local prevention of tobacco consumption. Although chromosome aberration analysis is a common method in genotoxicological studies, the limitations concerning false positive results due to unknown exposure to genotoxins or secondhand smoke (45), variations in metabolic genes $(46,47)$, individual genetic susceptibility and known effects of cigarette smoking on mutations, epigenetic modifications, and copy number changes (48), indicate that combined methods are required for accurate determination of the effects of cigarette smoking on genetic material.

\section{CONCLUSION}

In this study, we confirmed the genotoxicity of cigarette smoking. As blood samples included in this study are a portion of a slightly extended study group, for which we had previously analyzed micronuclei frequencies in lymphocytes and buccal epithelial cells, the current results provide novel information about clastogenic activity of tobacco smoke. These results also suggest that the previously reported increase in micronuclei frequencies could be the outcome of structural chromosome aberrations.

\section{CONFLICT OF INTEREST}

The authors declare no conflict of interest.

\section{REFERENCES}

1. Agudo A, Bonet C, Travier N, González CA, Vineis P, Bueno-deMesquita $\mathrm{HB}$, et al. Impact of cigarette smoking on cancer risk in the European prospective investigation into cancer and nutrition study. J Clin Oncol. 2012;30(36):4550-7.

http://dx.doi.org/10.1200/JC0.2011.41.0183.

2. Pereira CS, Juchniuk de Vozzi MS, Dos Santos SA, Vasconcelos MA de Paz CC, Squire JA, et al. Smoking-induced chromosomal segregation anomalies identified by FISH analysis of sperm. Mol Cytogenet. 2014;7(1):58.

http://dx.doi.org/10.1186/s13039-014-0058-7.

3. DeMarini DM. Genotoxicity of tobacco smoke and tobacco smoke condensate: a review. Mutat Res. 2004;567(2-3):447-74

http://dx.doi.org/10.1016/j.mrrev.2004.02.001.

4. Pfeiffer P, Goedecke W, Obe G. Mechanisms of DNA double-strand break repair and their potential to induce chromosomal aberrations. Mutagenesis. 2000;15(4):289-302.

http://dx.doi.org/10.1093/mutage/15.4.289.

5. Iliakis G, Wang H, Perrault AR, Boecker W, Rosidi B, Windhofer F, et al Mechanisms of DNA double strand break repair and chromosome aberration formation. Cytogenet Genome Res. 2004;104(1-4):14-20.

http://dx.doi.org/10.1159/000077461.

6. Hoffmann D, Hoffmann I. Letters to the editor, tobacco smoke components. Beitr Tabaksforsch Int. 1998;18(1):49-52. DOI: $10.2478 /$ cttr-2013-0668.

7. Thielen A, Klus $\mathrm{H}$, Muller L. Tobacco smoke: unraveling a controversial subject. Exp Toxicol Pathol. 2008;60(2-3):141-56. 
http://dx.doi.org/10.1016/j.etp.2008.01.014.

8. Borgerding M, Klus H. Analysis of complex mixtures-cigarette smoke. Exp Toxicol Pathol. 2005;57(Suppl 1):43-73.

http://dx.doi.org/10.1016/j.etp.2005.05.010.

9. Kaina B, Ziouta A, Ochs K, Coquerelle T. Chromosomal instability, reproductive cell death and apoptosis induced by 06-methyleguanine in Mex-, Mex+, and methylation-tolerant mismatch repair compromised cells: facts and models. Mutat Res. 1997;381(2):227-41.

http://dx.doi.org/10.1016/S0027-5107(97)00187-5.

10. Christmann M, Kaina B. O(6)-methylguanine-DNA methyltransferase (MGMT): impact on cancer risk in response to tobacco smoke. Mutat Res. 2012;736(1-2):64-74.

http://dx.doi.org/10.1016/j.mrfmmm.2011.06.004.

11. Hagmar L, Stromberg U, Tinnerberg H, Mikoczy Z. The usefulness of cytogenetic biomarkers as intermediate endpoints in carcinogenesis. Int J Hyg Environ Health. 2001;204(1):43-7.

http://dx.doi.org/10.1078/1438-4639-00071.

12. Bonassi S, Znaor A, Ceppi M, Lando C, Chang WP, Holland N, et al. An increased micronucleus frequency in peripheral blood lymphocytes predicts the risk of cancer in humans. Carcinogenesis. 2007:28(3):625-31. http://dx.doi.org/10.1093/carcin/bgl177.

13. Pryor WA. Cigarette smoke radicals and the role of free radicals in chemical carcinogenicity. Environ Health Perspect. 1997;105(4):875-82. http://dx.doi.org/10.1289/ehp.97105s4875.

14. Uma AN, Dhananjay SK, Aroul TT. Chromosomal aberrations: a tool for early diagnosis of cancer in smokers in a rural Pondicherry population, India. Int J Curr Micobiol App Sci. 2014;3(10):587-93.

15. Yadav JS, Kler RS, Chadha P, Yadav AS. Spontaneous chromosomal aberrations in human populations of five endogamous groups of Haryana. J Cytol Genet. 2002;3(NS):121-6.

16. Sierra-Torres MS, Arboleda-Moreno YY, Hoyos LS, Sierra-Torres CH. Chromosome aberrations among cigarette smokers in Colombia. Mutat Res. 2004;562(1-2):67-75.

http://dx.doi.org/10.1016/j.mrgentox.2004.05.006.

17. Bonassi S, Coskun E, Ceppi M, Lando C, Bolognesi C, Burgaz S, et al. The HUman MicroNucleus project on eXfoLiated buccal cells (HUMN(XL)): the role of life-style, host factors, occupational exposures, health status, and assay protocol. Mutat Res Rev Mutat Res. 2011;728(3):88-97.

http://dx.doi.org/10.1016/j.mrrev.2011.06.005

18. Yadav AS, Saini M. Increased frequency of nuclear anomalies in exfoliated buccal mucosa of cigarette smokers. J Entomol Zool Stud. 2015;3(2):07-10.

19. Feki-Tounsi M, Khlifi R, Mhiri MN, Rebai A, Hamza-Chaffai $A$. Cytogenetic damage in the oral mucosa cells of bladder cancer patients exposed to tobacco in Southern Tunisia. Environ Sci Pollut Res Int. 2014;21(22):12922-7.

http://dx.doi.org/10.1007/s11356-014-3200-5.

20. Naderi NJ, Farhadi S, Sarshar S. Micronucleus assay of buccal mucosa cells in smokers with the history of smoking less and more than 10 years. Indian J Pathol Microbiol. 2012;55(4):433-8.

http://dx.doi.org/10.4103/0377-4929.107774.

21. Balansky R, Izzotti A, D’Agostini F, Longobardi M, Micale RT, La Maestra S, et al. Assay of lapatinib in murine models of cigarette smoke carcinogenesis. Carcinogenesis. 2014;35(10):2300-7.

http://dx.doi.org/10.1093/carcin/bgu154.

22. Haverić A, Haverić S, Ibrulj S. Micronuclei frequencies in peripheral blood and buccal exfoliated cells of young smokers and non-smokers. Toxicol Mech Methods. 2010;20(5):260-6.

http://dx.doi.org/10.3109/15376516.2010.482962.

23. Bonassi S, Hagmar L, Strömberg U, Montagud AH, Tinnerberg H, Forni A, et al. Chromosomal aberrations in lymphocytes predict human cancer independently of exposure to carcinogens. European Study Group on Cytogenetic Biomarkers and Health. Cancer Res. 2000;60(6):1619-25.

24. Mitelman F. An International System for Human Cytogenetic Nomenclature (1995): Recommendations of the International Standing Committee on Human Cytogenetic Nomenclature. Memphis, Tenn: Karger; 1995.

25. Hammer O, Harper DAT, Ryan PD. PAST: Paleontological statistics software package for education and data analysis. Palaeontologia Electronica. 2001;4(1):9.

26. Klebaner D, Huang Y, Hui Q, Taylor JY, Goldberg J, Vaccarino V, et al. $X$ chromosome-wide analysis identifies DNA methylation sites influenced by cigarette smoking. Clin Epigenetics. 2016;8:20.

http://dx.doi.org/10.1186/s13148-016-0189-2.

27. Lee KWK, Richmond R, Hu P, French L, Shin J, Bourdon C. Prenatal exposure to maternal cigarette smoking and DNA methylation: epigenome-wide association in a discovery sample of adolescents and replication in an independent cohort at birth through 17 years of age. Environ Health Perspect. 2015;123(2):193-9.

DOI: 10.1289/ehp.1408614.

28. Bonassi S, Norppa H, Ceppi M, Strömberg U, Vermeulen R, Znaor A, et al. Chromosomal aberration frequency in lymphocytes predicts the risk of cancer: results from a pooled cohort study of 22358 subjects in 11 countries. Carcinogenesis. 2008;29:1178-83. http://dx.doi.org/10.1093/carcin/bgn075.

29. Ibrulj S, Krunic-Haveric A, Haveric S, Pojskic N, Hadziselimovic R. Micronuclei occurrence in population exposed to depleted uranium and control human group in correlation with sex, age and smoking habit. Med Arh. 2003;58(6):335-8.

30. Nefic $\mathrm{H}$, Handzic I. The effect of age, sex, and lifestyle factors on micronucleus frequency in peripheral blood lymphocytes of the Bosnian population. Mutat Res. 2013;753(1):1-11.

http://dx.doi.org/10.1016/j.mrgentox.2013.03.001.

31. Ibrulj S, Haverić $S$, Haverić A. Chromosome aberrations as bioindicators of environmental genotoxicity. Bosn J Basic Med Sci. 2007;7(4):311-6.

32. OECD. In vitro mammalian chromosomal aberration test - OECD guideline for the testing of chemicals, TG 473. Adopted 26 September 2014.

33. Shi Q, Ko E, Barclay L, Hoang T, Rademaker A, Martin RE. Cigarette smoking and aneuploidy in human sperm. Mol Reprod Dev. 2001;59(4):417-21. http://dx.doi.org/10.1002/mrd.1048.

34. Dumanski JP, Rasi C, Lönn M, Davies H, Ingelsson M, Giedraitis V, et al. Smoking is associated with mosaic loss of chromosome $Y$. Science. 2015;347(6217):81-3. http://dx.doi.org/10.1126/science.1262092.

35. Ibrulj S, Haverić S, Haverić A. Complementarity of standard cytogenetic assays. Bosn J Basic Med Sci. 2008;8(1):27-33.

36. Garaj-Vrhovac V, Fucic A, Horvat D. The correlation between the frequency of micronuclei and specific chromosome aberrations in human lymphocytes exposed to microwave radiation in vitro. Mutat Res. 1992;281(3):181-6. http://dx.doi.org/10.1016/0165-7992(92)90006-4.

37. Fenech M, Kirsch-Volders M, Natarajan AT, Surralles J, Crott JW, Parry J, et al. Molecular mechanisms of micronucleus, nucleoplasmic bridge and nuclear bud formation in mammalian and human cells. Mutagen. 2011;26(1):125-32. http://dx.doi.org/10.1093/mutage/geq052.

38. Zenic N, Terzic A, Rodek J, Spasic M, Sekulic D. Gender-specific analyses of the prevalence and factors associated with substance use and misuse among Bosniak adolescents. Int J Environ Res Public Health. 2015;12(6):6626-40. http://dx.doi.org/10.3390/ijerph120606626.

39. Ibisevic M, Avdic A, Osmanovic E, Kadric N, Avdic S. Cigarette smoking among students at the University of Tuzla. Med Arch. 2015;69(2):127-9. 
http://dx.doi.org/10.5455/medarh.2015.69.127-129.

40. Padjen I, Dabić M, Glivetić T, Biloglav Z, Biočina-Lukenda D, Lukenda J. The analysis of tobacco consumption in Croatia - Are we successfully facing the epidemic? Cent Eur J Public Health. 2012;20(1):5-10.

41. Idrizovic K, Zenic N, Tahirail E, Rausavljevic N, Sekulic D. Cigarette smoking among 17-18 year old adolescents - prevalence and association with sociodemographic, familial, sport, and scholastic factors. Med Pr. 2015;66(2):153-63.

http://dx.doi.org/10.13075/mp.5893.00104.

42. Hublet $A$, Bendtsen $P$, de Looze ME, Fotiou $A$, Donnelly $P$, Vilhjalmsson $R$, et al. Trends in the co-occurrence of tobacco and canabis use in 15-year olds from 2002 to 2010 in 28 countries of Europe and North America. Eur J Public Health. 2015;25(2):73-5.

http://dx.doi.org/10.1093/eurpub/ckv032.

43. Zenic N, Ostojic L, Sisic N, Pojskic H, Peric M, Uljevic O, et al. Examination of the community-specific prevalence and factors associated with substance use and misuse among rural and urban adolescents: a cross-sectional analysis in Bosnia and Herzegovina. BMJ Open. 2015;6(5):e009446. http://dx.doi.org/10.1136/bmjopen-2015-009446.
44. Ibrulj S, Haverić S, Haverić A, Durmić-Pašić A, Marjanović D. Effect of war and postwar genotoxins on micronuclei frequency in Sarajevo study group. Bosn J Basic Med Sci. 2006;6(4):54-7.

45. Balachandar V, Kumar BL, Suresh K, Sasikala K. Evaluation of chromosome aberrations in subjects exposed to environmental tobacco smoke in Tamilnadu, India. Bull Environ Contam Toxicol. 2008;81(3):270-6.

http://dx.doi.org/10.1007/s00128-008-9489-3.

46. Chandirasekar R, Suresh $K$, Jayakumar R, Venkatesan R, Lakshman Kumar B, Sasikala K. XRCC1 gene variants and possible links with chromosome aberrations and micronucleus in active and passive smokers. Environ Toxicol Pharmacol. 2011;32(2):185-92.

http://dx.doi.org/10.1016/j.etap.2011.05.002.

47. Hemminki K, Frank C, Försti A, Musak L, Kazimirova A, Barancokova M, et al. Metabolic gene variants associated with chromosomal aberrations in healthy humans. Genes Chromosomes Cancer. 2015;54(4):260-6. http://dx.doi.org/10.1002/gcc.22239.

48. Pirini F, Guida E, Lawson F, Mancinelli A, Guerrero-Preston R. Nuclear and mitochondrial DNA alterations in newborns with prenatal exposure to cigarette smoke. Int J Environ Res Public Health. 2015;12(2):1135-55. 